\title{
TYCHITE AND NORTHUPITE FROM LAKE KATWE, UGANDA
}

\author{
P. H. Nixon, W. H. Morton and O. von Knorring
}

Nixon, P. H., Morton, W. H. and von Knorring, O 1971: Tychite and northupite from Lake Katwe, Uganda. Bull. Geol. Soc. Finland 43, 125-130.

P. H. Nixon and W. H. Morton, Formerly of Uganda Geological Survey.

O. von Knorring, University of Leeds, England.

\section{Introduction}

Lake Katwe is the largest of the saline crater lakes within the Katwe-Kikorongo volcanic field in Uganda (Figs. 1-3). It lies on the floor of the Western Rift Valley and south-east of the Ruwenzori range. This is an unusually dry area missing much of the rain that falls on Ruwenzori and on the country east of the Buhwezu scarp. Lake Katwe consists of at least three intersecting explosion craters blown through subaqueous volcanic tuffs. The total lake area is at present about $2 \frac{1}{2} \mathrm{~km}^{2}$, comprising a circular part of $1 \mathrm{~km}$ across and a smaller embayment to the east formed from an adjacent crater. The third and smaller crater is permanently dry. Lying only $250 \mathrm{~m}$ from Lake Edward, the surface of the crater lake is some $30 \mathrm{~m}$ below the latter's. Radiocarbon dating indicates that most of the evaporites have accumulated within the last 11000 years.

The brine of Lake Katwe has the following composition:

$\begin{array}{lrc}\mathrm{Na} & 150 & \mathrm{~g} / \text { litre } \\ \mathrm{K} & 37 & » \\ \mathrm{CO}_{3} & 47 & » \\ \mathrm{HCO}_{3} & 5 & » \\ \mathrm{Cl} & 154 & » \\ \mathrm{SO}_{4} & 62 & » \\ \mathrm{Br} & 1.2 & \end{array}$

A good description of Lake Katwe has been given by Wayland (1934) and Holmes (1956) has described the volcanic tuffs and ejectamenta connected with the crater.

During 1967 a programme of drilling was undertaken by the Geological Survey of Uganda

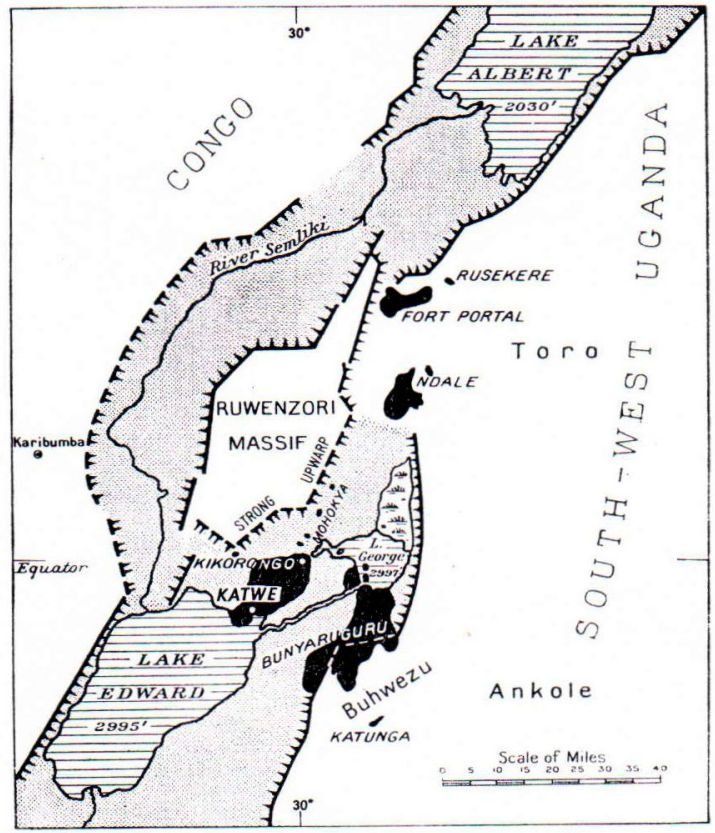

Fig. 1. The Katwe area in relation to the Western Rift (after Holmes, 1965). Black areas indicate recent volcanicity. 
to determine the nature and thickness of the evaporite deposits which underlie the lake (Morton, in preparation). Cores were obtained from three boreholes drilled to depths of between 125 and 150 feet, and a hand operated Banka drill was used to obtain samples from a depth of 45 feet.

\section{Geological Environment}

In the main part of the lake evaporite minerals extend down to about 140 feet with prominent clay layers at about 55, 100 and 115 feet. In the eastern embayment the evaporite sequence is thinner and extends down to about 25 feet only.

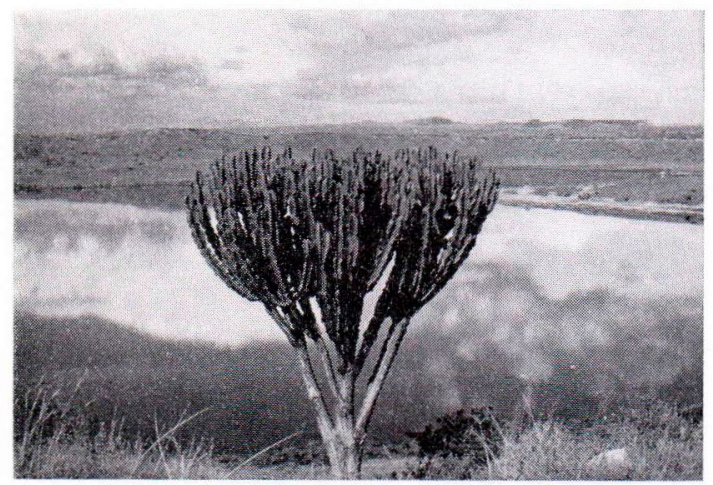

Fig. 2. Lake Katwe, looking north-east.

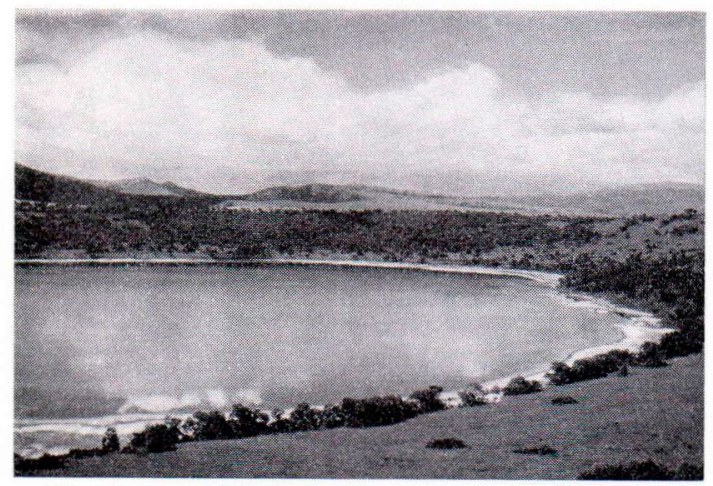

Fig. 3. Lake Nyamunuka, north-east of Katwe.
Trona, burkeite, hanksite and nahcolite are the most abundant evaporite minerals, with halite in minor amounts only, although chloride is the dominant anion in the lake itself and in the saturated brines which permeated the deposit.

Tychite is restricted to the main part of the lake where it is embedded in the clay layers. It is most abundant in a 10 to $15 \mathrm{ft}$. thick clay layer which occurs about $115 \mathrm{ft}$. down, where in parts it makes up over $10 \%$ of the rock. It is also present in the clay layers at about 55 and $100 \mathrm{ft}$. and below $140 \mathrm{ft}$. Northupite occurs in much smaller amounts in the clay layers at about $115 \mathrm{ft}$.

By far the greatest concentration of northupite, to the exclusion of tychite, occurs in the eastern embayment of Katwe in dark grey clay below a depth of $25 \mathrm{ft}$.

The clay that bears tychite and northupite is dark grey, organic, plastic and usually structureless but it may possess poorly defined dark and light varve-like banding about $1 \mathrm{~mm}$. thick. The banding is disturbed in the vicinity of each crystal due to compaction or post-depositional crystal growth.

Apart from an occurrence at $150 \mathrm{ft}$. in a greenish clay both tychite and northupite were rarely found in any other of the locally varied brown, pale grey, blue or yellowish clays nor in fissile layers within these or the dark grey plastic clays. They are also thought to be lacking from the main evaporite sequences. A few crystals recovered from the layers of evaporite minerals are suspected to have been derived by caving within the borehole from higher clay horizons.

Judging by their distribution within the crater it would appear that the relatively shallow, shore-like conditions of the Katwe embayment favoured carbonate-chloride (northupite) precipitation contrasting with carbonate-sulphate (tychite) precipitation in the deeper parts of the main crater. However, it is possible that the two areas, which overlie separate vents, initially developed at a lower level, as two independent lakes fed by juvenile salt springs of differing composition. 


\section{Previous occurrences}

Tychite, $\mathrm{Na}_{6} \mathrm{Mg}_{2}\left(\mathrm{SO}_{4}\right)\left(\mathrm{CO}_{3}\right)_{4}$

Apart from the type locality at Borax (Searles) Lake, San Bernardino County, California described by Penfield and Jamieson (1905) and traces of the mineral in the Green River Formation, Wyoming, U.S.A. (Fahey, 1962) there do not appear to be any other recorded occurrences of tychite.

At Searles Lake it was found in borehole samples from a clay bed associated with northupite, gaylussite, thenardite, schairerite and pirssonite. Its mode of occurrence is thus similar to that at Katwe although it is apparently much rarer.

Northupite, $\mathrm{Na}_{3} \mathrm{MgCl}\left(\mathrm{CO}_{3}\right)_{2}$

The three described occurrences of northupite have been summarised by Fahey (1962). The original locality was described by Foote (1895) and named in honour of C.H. Northup of San Jose, California, who found the first specimens of this mineral in a boring known as the "New Well» in Searles Lake. According to Mr. Northup, the mineral was formed in a stratum of clay about 450 feet below the surface.

The second location of northupite is Borax Lake, Lake County, California, where it was found by Vonsen (1935) in association with pirssonite and gaylussite in massive trona.

The third occurrence is in shales of the Eocene Green River Formation, Wyoming (Fahey 1962) where it occurs with shortite, trona, pirssonite and gaylussite. It occurs massive filling cracks and vugs; euhedral crystals are rare.

\section{Mineralogy}

Due to their similar characteristics both northupite and tychite are described together, but where appropriate, diagnostic differences are noted.

\section{Habit}

Octahedral with rare slight cube face modifications. The (111) faces are usually equally developed although occasionally a pair of opposite faces may be somewhat larger, giving a flattened rhombohedron appearance.

The octahedral faces may be striated at right angles to the edges (Fig. 4). In such cases a gentle re-entrant angle in the centre of each edge extends to a slight depression in the centre of each face. This growth feature has led to zones of weakness sometimes marked by cracks which extend from the centre of each face to join the edge perpendicularly. The crystal may break along these zones giving rise to a false »cleavage».

The larger crystals of northupite have cavernous and stepped (hopper) faces. These depressions combined with the observed high proportion of inclusions in the larger crystals are indicative of rapid growth (Dana, 1932, p. 200).

\section{Intergrowths}

Conformable intergrowths on (111) give a castellated outline to the crystals (Fig. 4). Aggregates resembling penetration twins in which a cube or octahedral axis of two crystals coincide are rare. The relationship is usually irregular and due to accidental conditions of growth.

\section{Physical properties}

Cleavage is not developed although as noted above there is a tendency to break along growthweakness zones often roughly parallel to the crystal faces. The crystals are brittle with a conchoidal or hackly fracture and a greasy lustre on the broken surface (vitreous lustre on the clean crystal surfaces). Hardness is about 4 . 

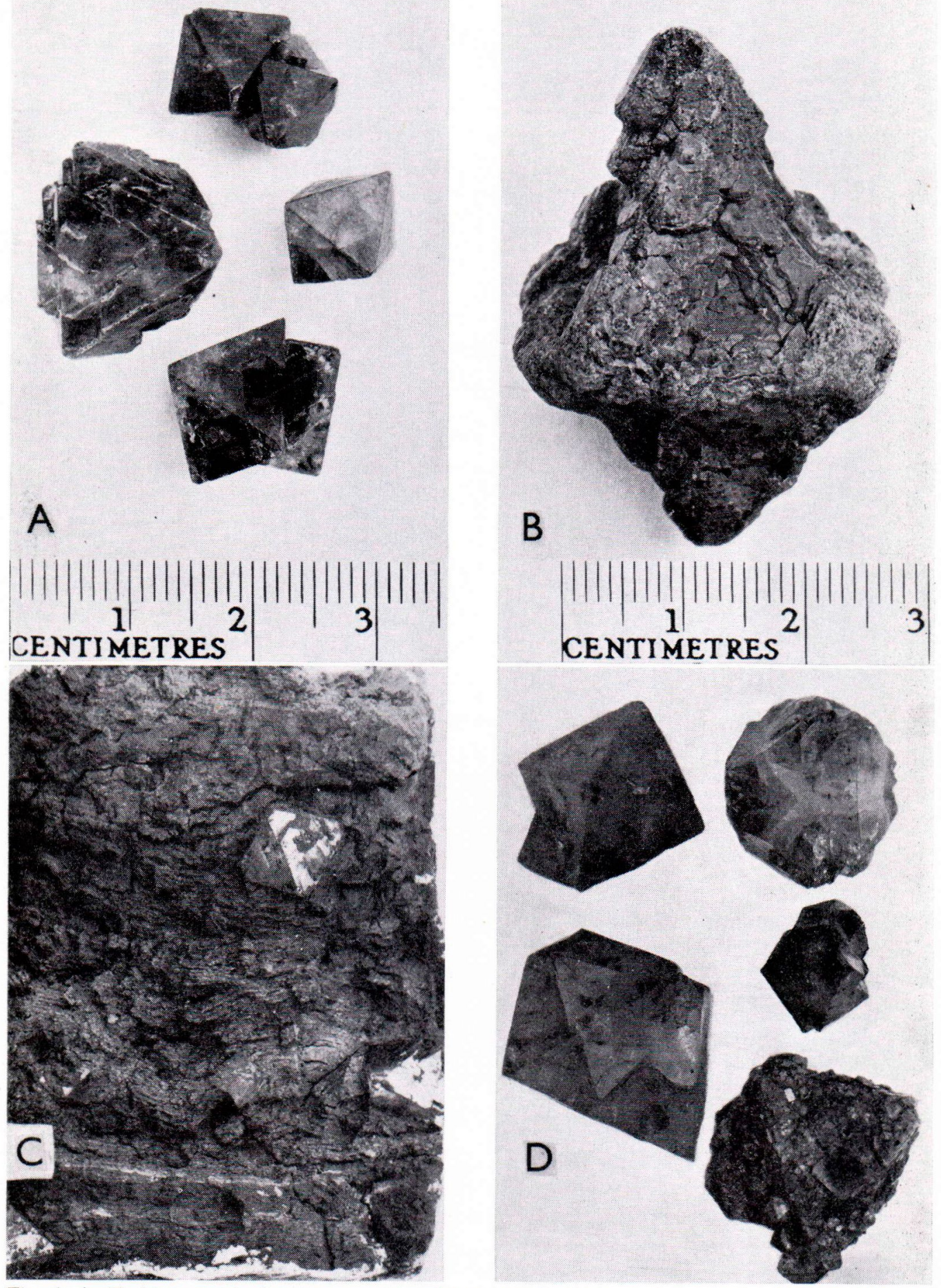

Fig. 4. A. Tychite crystals showing a variety of intergrowths from various depths between 55 and 150 feet below main part of Lake Katwe. B. Northupite crystal with hopper face development from eastern embayment of Lake Katwe at about 30 feet depth. C. Finely banded clay with tychite crystals at 115 feet depth below main part of Lake Katwe. D. Tychite from Lake Katwe. Crystal at top right shows cracks extending from gently incurving edges to centre on (111) face. Crystal below this shows slight cube modification. 


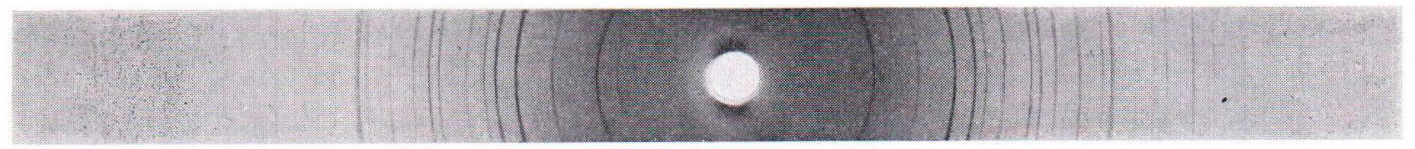

b

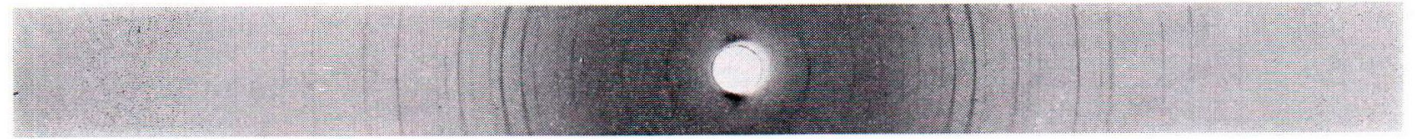

Fig. 5. Powder patterns of a) tychite and b) northupite. Cu-radiation.

Streak is white to grey (impure varieties). When free of inclusions the crystals are transparent.

\begin{tabular}{lc} 
& \multicolumn{1}{c}{ Tychite } \\
Size range: & Usually up to \\
& $1 \mathrm{~cm}$. (ma- \\
& ximum 2.5 \\
& $\mathrm{cms})$. \\
& \\
Colour: & Colourless \\
& and tinged \\
& with grey, \\
& green or \\
& yellow.
\end{tabular}

(111)

Fluorescence:

( $\lambda .2350$ and 2850 A)

Phosphorescence:

n, Na light:

D, $25^{\circ} / 4^{\circ} \mathrm{C}$
Little or no reaction

Perceptible

$1.508 \pm .001$

$2.580 \pm .01$
Contrasting properties of northupite and tychite from Katwe are given below.

\section{Nortbupite}

Usually up to $3 \mathrm{~cm}$. (maximum $5 \mathrm{cms}$.)

\section{Colourless and tinged with grey, green or yellow. Deep honey coloured and greenish black varieties occur. The latter contain mud inclusions. \\ Hopper faces common
on the larger crystals.}

Pale yellow fluorescence

Distinct

$1.515 \pm .001$

$2.377 \pm .01$
The powder patterns of tychite and northupite are shown in Fig. 5. The measured $d$-values (not reproduced here) agree well with those given by Miss Mrose for northupite in Fahey (1962) and for tychite by Keester et al. (1969).

\section{Inclusions}

These consist of greenish black organic and volcanic mud particles which are symmetrically arranged within the crystal lattice, especially that of the larger northupite crystals. The inclusions are arranged along the cube axes thus producing a stellate pattern within the crystals. Inclusions are also found in zones parallel to the crystal faces growth stages. A cross section of any crystal therefore generally shows both concentric and radial arrangements of inclusions. 
TABLE 1

Chemical analyses of tychite and northupite

\begin{tabular}{|c|c|c|c|c|c|c|c|}
\hline & 1 & 2 & 3 & 4 & 5 & 6 & 7 \\
\hline $\mathrm{Na}_{2} \mathrm{O} \ldots \ldots \ldots \ldots \ldots \ldots$ & 35.50 & 35.80 & 35.57 & 36.67 & 35.80 & 36.99 & 36.59 \\
\hline $\mathrm{MgO} \ldots \ldots \ldots \ldots \ldots \ldots$ & 15.10 & 14.76 & 15.80 & 16.05 & 15.39 & 16.08 & 15.98 \\
\hline $\mathrm{CaO} \ldots \ldots \ldots \ldots \ldots \ldots$ & 0.16 & - & - & 0.45 & - & - & 0.04 \\
\hline $\mathrm{Cl} \ldots \ldots \ldots \ldots \ldots \ldots \ldots \ldots$ & - & Nil & - & 14.06 & 13.06 & 14.10 & 14.01 \\
\hline $\mathrm{SO}_{3} \ldots \ldots \ldots \ldots \ldots \ldots \ldots$ & 15.10 & 15.68 & 15.07 & - & Nil & - & - \\
\hline $\mathrm{CO}_{2} \ldots \ldots \ldots \ldots \ldots \ldots \ldots$ & 33.83 & 33.36 & 33.50 & 35.20 & 36.19 & 35.12 & 35.72 \\
\hline Insol. . .............. & 0.04 & 0.06 & - & 0.12 & 0.81 & 1.02 & 0.68 \\
\hline & 99.73 & 99.66 & 99.94 & 102.75 & 101.25 & 103.31 & 103.06 \\
\hline $\mathrm{O}=\mathrm{Cl}$ & & & & 3.17 & 2.95 & 3.16 & 3.16 \\
\hline * Total of No. 4 includes $\mathrm{R}_{2}$ & $3,0.20$ & $01+80$ & $\Lambda_{2}$, & $99.58^{*}$ & 98.30 & 100.15 & $99.90^{\circ}$ \\
\hline
\end{tabular}

1. Tychite, Lake Katwe (analyst: O. von Knorring)

2. Tychite, Lake Katwe (analyst: H. C. Patel, Geol. Surv. Uganda)

3. Tychite, Borax Lake (Penfield and Jamieson, 1905)

4. Northupite, Lake Katwe (analyst: O. von Knorring)

\section{Chemistry}

The main feature of the chemical analyses (Table 1) is the absence of solid solution between the tychite and northupite under natural conditions. This has been further confirmed by testing several hundred crystals in a dilute solution of $\mathrm{AgNO}_{3}$ in $\mathrm{HNO}_{3}$. There was an immediate reaction to produce a white coating
5. Northupite, large single crystals with mud inclusions, Lake Katwe (analyst: H. C. Patel, Geol. Surv. Uganda) 6. Northupite, Searles Lake (Pratt, 1896)

7. Northupite, Green River formation, Sweetwater county, Wyoming (Fahey, 1962).

\section{REFERENCES}

DANA, E. S. (1932). A Textbook of Mineralogy. John Wiley \& Sons, New York, 4th Ed. p. 200.

Fahey, J. J. (1962). Saline Minerals of the Green River Formation. U. S. Geol. Surv., Prof. paper No. 405.

Foоте, W. M. (1895). Preliminary note on a new alkaline mineral. Am. J. Sci. 50, 3rd ser. 480-481.

Holmes, A. (1956). The ejectamenta of Katwe crater, south-west-Uganda. Verh. Geol. Mijn. Genoot. Ned. Kolon., 16, (Gedenkboek H. A. Brouwer), 139-166.

Keester, K. L., Johnson, E. G. and Vand, V. (1969). New data on tychite. Am. Min. vol. 54, 302-305.

Penfield, S. L. and Jamieson, G. S. (1905). On tychite, of $\mathrm{AgCl}$ on northupite but not on tychite. The distinction between the two minerals was clear cut and there were no doubtful or sluggish reactions that could be due to crystals of intermediate composition.

The inclusions of carbonaceous mud which characterise the larger »hopper» faced northupite crystals usually make up less than one per cent of the total by weight (Table 1 No. 5). a new mineral from Borax Lake, California. Am. J. Sc. 20. $217-224$.

Prate, J. H., (1896). On northupite; pirssonite, a new mineral; gaylussite and hanksite from Borax Lake, San Bernardino County California: Am. Jour. Sci., 2, 123-135.

Vonsen, Magnus (1935). The discovery of borates in California: Mineralogist, 3, No. 12, 23.

WAYLAND, E. J. (1934). Katwe. Uganda Journal, vol. 1, No. 2, 96-106.

Manuscript received, July, 51970. 